\title{
Locutionary act in motivating students at SMPN 2 Wungu
}

\author{
Bella Agustina Santoz ${ }^{1}$, Nuri Ati Ningsih ${ }^{1}$, Agita Risma Nurhikmawati ${ }^{1}$ \\ ${ }^{1}$ Department of English Teaching, Universitas PGRI Madiun, Indonesia
}

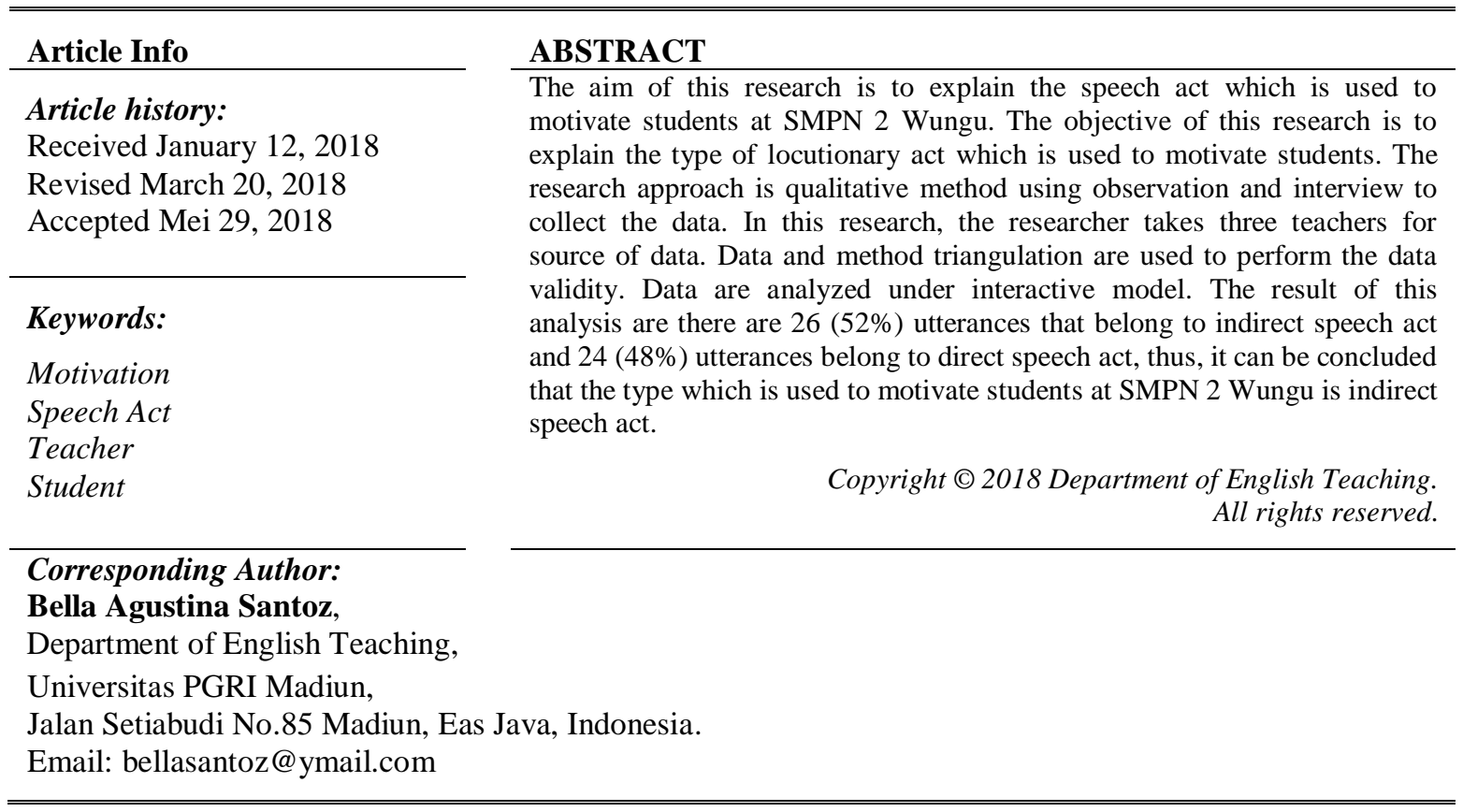

\section{INTRODUCTION}

English is an international language that many people said it is hard to be learnt. Here, the role of teacher as the motivator takes place to make the students be better in learning English. It can be done by giving motivation to the students. Gottfried (1990, in Lai 2011) defines academic motivation as "enjoyment of school learning characterized by a mastery orientation; curiosity; persistence; task-endogeny; and the learning of challenging, difficult, and novel tasks". The link between motivation and learning is strong. In the present study the causal-those who are motivated learn more and those who learn more become more motivated.

Searle points out that speaker's utterance meaning and the sentence meaning frequently diverge (Searle 1975). Utterances can be classified based on the structural forms (declarative, interrogative, and imperative) and three communicative functions (statement, question, command/request). The utterances can be analyzed using theory of direct and indirect speech act. Yule (1996) states that direct and indirect speech act concern with the way speaker uses in order to perform speech act. Searle (in Cutting 2002: 19) states direct speech act are used when speaker intends to communicate what the words he said literary means. It means that beyond those words, there is no other meaning that he expects the hearer to know or understand. Beside, Searle in Cutting (2002: 19) says that indirect speech acts used when the speaker wants to communicate more than what is communicate conventionally by the words he utters. It means there is something more than the literal meaning the words have. When the utterance is delivered by the teachers, the researcher should looking for 'speech situations', 'speech events', and 'speech act'. To help ethnographers of communications frame their 
investigation of speech acts and events, Hymes offers the mnemonic device of the SPEAKING grid as a heuristic. Though it is by no means his most significant contribution to sociolinguistics, the SPEAKING grid is perhaps the artifact most associated with Hymes as his popular legacy. The SPEAKING grid has been widely accepted in the ethnography of communication. The eight components of the SPEAKING mnemonic are:

(S) Setting including the time and place, physical aspects of the situation such as arrangement of furniture in the classroom;

(P) participant identity including personal characteristics such as age and sex, social status, relationship with each other;

(E) ends including the purpose of the event itself as well as the individual goals of the participants;

(A) act, sequence or how speech acts are organized within a speech event and what topic/s are addressed;

(K) key or the tone and manner in which something is said or written;

(I) instrumentalities or the linguistic code i.e. language, dialect, variety and channel i.e. speech or writing;

(N) norm or the standard socio-cultural rules of interaction and interpretation; and

(G) genre or type of event such as lecture, poem, letter.

By using the theory of speech act and ethnography of communication, the researcher proposes to find the locutionary act in the utterances spoken by teachers at SMPN 2 Wungu to motivate students in order to be better learning English. To prove that this research authentic research which is never done before, the researcher provide two previous research about speech act in the teaching learning process. The first research is "Development of a tool to evaluate lecturers' verbal repertoire in action" by R.M. van der Rijst*, G.J. Visser-Wijnveen, N. Verloop and J.H. van Driel. The research is a research about lecturers' verbal action during teaching practice in university. This research uses Austin speech act theory as the tool to analyze the data. The finding of this research showed that the speech act tool provides a detailed description of lecturer's verbal action in teaching practice. The second research is "An Analysis of Speech Acts Produced By Teachers and Students to Facilitate Teaching and Learning at SDN 10 Pringgasela East Lombok” by Merdana, Seken, $\mathrm{K}$ and Adi Jaya Putra. This research intended to describe, analyze, and explain types, functions, instructional functions of speech acts produced, and politeness strategies employed in the classroom. The subjects of the study were the teachers and the students. the founding of this research is that teacher produced more utterances than students did and also the types of the utterances that produced by both teachers and students during the learning process. From the two researches, none of them are analyze the locutionary act to motivate students. So, this research is original research from researcher.

\section{METHOD}

This research uses qualitative research. Data are collected through observation and interview in the field, which the utterances spoken by teachers to motivate students during English teaching learning process. This research was done in SMPN 2 Wungu, Madiun Regency. Data of this research are consists of two types (1) data from teacher's utterances and (2) data from field note. The data from teacher's utterances consist of the type of speech act and structural forms that usually used to motivate students. Data from field note consist 
of descriptive field note about what happened during the utterances are spoken. The data is collected using nonparticipant observation, which means the researcher does not participate directly in the teaching learning process. The researcher does the recording and takes a field note. A voice recorder becomes the tools to collect the data in this research. Data are analyzed using Interactive Model (Miles and Huberman, 1994) with three main components: (1) data reduction, (2) data display, (3) conclusion drawing and verification. The data validating technique uses triangulation method, which from source of data triangulation (recording result and field note) and method triangulation (interview and observation).

\section{RESULT AND DISCUSSION}

In this research, the researcher focuses on what types which is used by the teachers at SMPN 2 WunguMadiun to motivate their students during the learning process. The motivation here means a stimulant for achieving a specific target, to be motivated means to progress or to be in motion to do something (Johnstone 1999, p. 146, Ryan and Deci 2000, in TengkuSepora 2012). Therefore, any acts which is done by the teachers that give the effect to students to be better in any ways include as the data of this research.

The result of the analysis which can be seen in the chart 1 , shows sentence has structural forms that can be divided into declarative, interrogative and imperative.

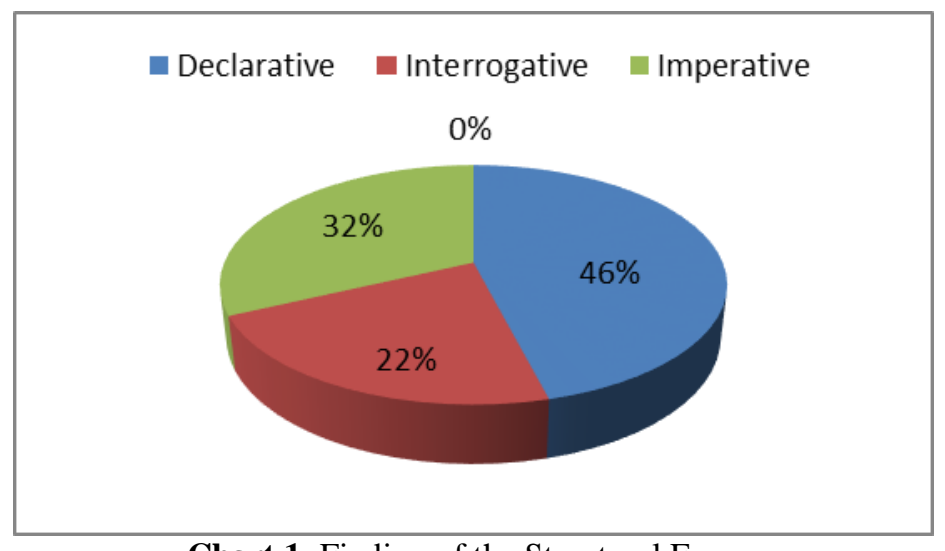

Chart 1. Finding of the Structural Forms

From 50 sentences that has been analyzed, $23(46 \%)$ utterances belong to declarative. The utterances that belong to Interrogative are $11(22 \%)$ utterances. There are $16(32 \%)$ utterances that belong to imperative. Declarative form has the largest score which means this is the type of structural forms that most used by teachers. The use of declarative means teachers prefers giving statement about what students do in the classroom during the English teaching learning process in order to make students do better. Imperative come after with quiet big different score from declarative forms. Imperative means teachers giving command/ request to the students about what happened in the classroom. Interrogative is on the last place with the lowest score in the structural forms which means teachers are rarely use question form to motivate students. Based on the result, it can be concluded that the three teachers prefer use declarative forms to motivate students at SMPN 2 Wungu. In other words, teachers prefer giving statements to make students do better in the English teaching learning process. 


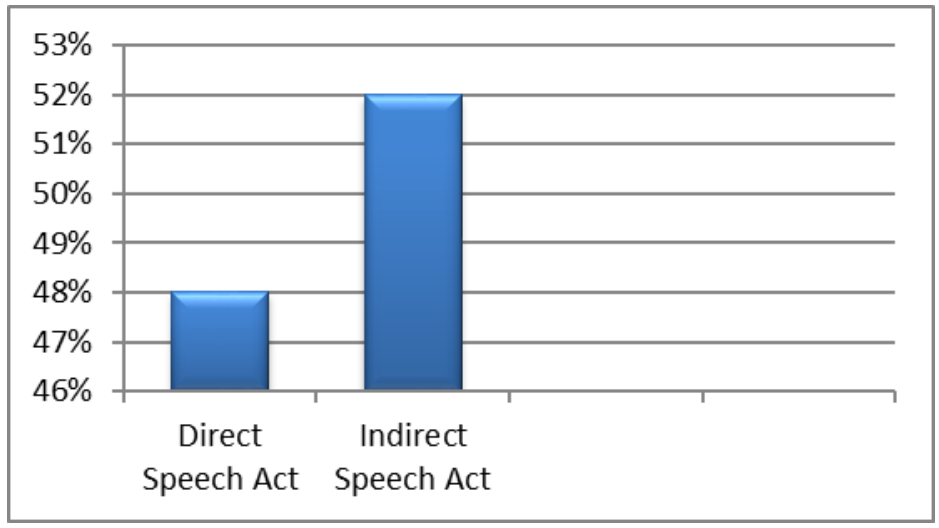

Chart 2. Finding of Speech Act Types

Chart 2 shows the result of speech act type (locutionary). Locutionary act has two types of speech act, direct and indirect speech act. From 50 data utterances spoken by teacher during English teaching learning process, there are $26(52 \%)$ utterances that belong to indirect speech act and $24(48 \%)$ utterances belong to direct speech act. Direct speech act means teachers utter the utterances directly, in other words, beyond those words there is no other meaning that he expects the hearer to know or understand. Then, indirect speech act that indirect speech acts used when the speaker wants to communicate more than what is communicate conventionally by the words he utters (Searle in Cutting (2002: 19)). It means there is something more than the literal meaning the words have. Based on the result, it can be seen that teachers often use direct speech act than indirect speech act when delivering the utterances to motivate students in learning English in the classroom. from the result, it can be seen that there is just two differences between the amount of direct (24 utterances) and indirect (26 utterances) speech act. Based on that result, the researcher concludes that it is not significant enough to say that all teachers at SMPN 2 Wungu prefer use indirect speech act.

The analysis which is done by the researcher is to find the type of locutionary act from the utterances produced by teachers in the learning process. The result shows that teachers mostly used indirect speech act to motivate students. A little bit different result has been found in the other research. If in this research, the researcher try to find out the locutionary act, research from Merdana, Seken\&Adi Jaya (2013) “An Analysis of Speech Acts Produced by Elementary School teachers and Students to Facilitate Teaching and Learning at SDN 10 Ptinggasela East Lombok" is try to find out the type of illocutionary act which is used by the teachers. It is a research that analyze the utterances of teachers and students during the learning process. The research is done to find out what is the function of the utterances which is produced by teachers. One of the results from the function is to control, organizational and motivational or evaluative functions. Another research about speech act which is used in the learning process is come from Wulansari, Y. \&Suhartini, C. (2015) “Directive Speech Acts Realization of Indonesian EFL Teacher”. The research examines the types and functions of directive speech act performed by an Indonesian EFL teacher in one senior high school in Kuningan, Indonesia. The result of this research shows that commands, request, suggestions are the types of directive speech act which is used by the teacher. It was also found that the most frequent type which is found is command. Another finding is that there are five functions seized by the directives, they are elicitation, instruction, advice, threat, and attention-getter. The most frequent function of directives used is elicitation. 
From the two different researches which is found, it can be seen that both of those research only focus on analyzing the function of the utterances which is produced by the teachers whether elementary school teachers or senior high school teacher. Both of the researches are almost the same, the utterances which are produced by teachers were analyzed using speech act theory to find out the function of directive speech act. It was not explained how teachers produced the utterances, such as using direct or indirect speech act. Different from those, in this research, the researcher try to find out how the teacher produced the utterances during the learning process. Also, the researcher has been decided first the function of the utterances spoken which is to motivate students. That is why the researcher will be more focus in one topic.

\section{CONCLUSION}

The data for this research are collected through observation and interview in the English classes from three teachers. It is analyzed by the structural forms and speech act types. The result shows that declarative type of structural forms is the most used type with the score $23(46 \%)$ which means teachers prefer giving statements to motivate students. Then, to deliver the statements, teachers often uses indirect speech act. It can be seen from the result that indirect speech act has $26(56 \%)$ utterances from 50 utterances that has been analyzed. It means that teachers prefer ask students to understand the meaning delivered by themselves tough it is not significant enough to say that all teachers at SMPN 2 Wungu uses indirect speech act because of there are just 2 difference in the utterances found.

\section{REFERENCES}

Austin, J.L. (1962). How to do Things with Words. Oxford University Press.

Bublitz, W. \& Norrick, N. R. (2011). Foundations of Pragmatics. Berlin: Walter de Gruyter

Cutting, J. (2002). Pragmatic and Discourse: A Resource Book for Students. London and New York: Routledge.

Creswell, J. W. (2003). Research Design Qualitative, Quantitative, and Mixed Method Approaches $2^{\text {nd }}$ edition. Sage Publications.

Johnstone, B. \& Marcellino, W. (2010). Dell Hymes and Ethnography of Communication.Carnegie Mellon UniversityResearch Showcase @ CMU.

Lai, E. R. (2011). Motivation: A Literature Review. Retrieved from http://www.pearsonassessments.com/

Given, L. M. (2008). The Sage Encyclopedia of Qualitative Research Methods Vol. 1\&2.California : Sage Publication.

Merdana, S. K. \& Putra, A. J. (2013). An Analysis of Speech Acts Produced by Elementary School Teachers and Students to Facilitate Teaching and Learning at SDN 10 Pringgasela East Lombok. E-Journal Program PascasarjanaUniversitas PendidikanGanesha Volume 1.

Miles, M. B. \& Huberman, A. M. (1994). Qualitative Data Analysis, $2^{\text {nd }}$ Edition. California: Sage Publication.

R.M. van der Rijst*, G.J. Visser-Wijnveen, N. Verloop and J.H. van Driel. (2014). Development of A Tool to Evaluate Lecturers' Verbal Repertoire in Action. Teaching in Higher Education: Routledge.

Sepora, T. \& Jafari, S. M. (2012). Motivation, Its Types, and Its Impacts in Language Learning. International Journal of Business and Social Science.

Wulansari, Y. \&Suhartini, C. (2015). Directive Speech Acts Realization of Indonesian EFL Teacher.English Review: Journal of English Education, 3(2),223-229.

Yule, G. (1996). Pragmatics. Oxford University Press. 